\title{
The Decision of Choosing Course in the Era of Covid 19 through the Telemarketing Program, Personal Selling and College Image
}

\author{
Ester Hervina Sihombing ${ }^{1}$ Nasib $^{2}$ \\ ${ }^{1}$ Informatics Management, Politeknik Unggul LP3M, Indonesia \\ ${ }^{2}$ STIE Mahkota Trico Unggul, Indonesia \\ esterhervinasihombing@gmail.com
}

\section{Abstract}

The main focus in this study is to analyze the influence of variable telemarketing, personal selling and the image of universities. This research was conducted at a high school in Medan. Data collection using questionnaires with the technique of withdrawing samples as many as 237 respondents through withdrawal by way of snowball sampling. The results showed that telemarketing had a positive effect on college decisions. Personal selling has a positive effect on the decision to choose a lecture. The image of the college has a positive and significant positive effect on the decision to choose a college.
Keywords

choosing, telemarketing, personal selling, image

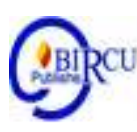

\section{Introduction}

The Covid-19 pandemic caused everyone to behave beyond normal limits as usual. One of the behaviors that can change is deciding the decision to choose a college. The problem that occurs in private universities during covid 19 is the decrease in the number of prospective students who come to campus to get information or register directly to choose the department they want. In addition, worries are also complained to parents when their child intends to go to college or even come directly to the desired campus. Surely this is such a problem for colleges and parents.

The decision to determine which college best suits the needs and abilities of a prospective student is difficult. This will be a confusing taste while parents, friends and advertisements from the college are many dreaming of a prospective student (Setyowati, 2019). So that makes the candidate will consider well in deciding which college he will choose in achieving his dream so that the future life will be better (Amron, 2018).

A consumer's decision will continue to change over time. Where the demands and expectations reached by consumers should be responded wisely to stakeholders (Azhari, 2017) (Hidayat, 2017). So forced for private universities that want to remain in the scope of a healthy company will make improvement efforts (Suwendra, 2014). Therefore, a strong committee, especially the foundation and management, is required to meet all the demands and needs that prospective new students need. In essence, universities are not business land, but do not lose or be unable to make payments for operational activities as well as the development of support facilities (Susanto, 2019).

This research was conducted at one of the private universities in Medan, namely at Polytechnic Unggul LP3M. Currently, it can be said that the number of students applying is down drastically when compared to last year. Various efforts have also been made, especially for marketing to bring in or get prospective new students. However, the Covid 19 pandemic caused all efforts not to be as maximal as expected. As a form of business that is done by telemarketing to the prospective student. 
Marketing promotion strategies that use communication and personal technology are trained to take a stand in planned targeting activities in targeted consumer groups (Budiarto, 2011). The development of marketing communication that changes very rapidly through advertising is not the only or the most important thing in establishing brand equity and driving sales, but can also be a mean which increases equity and drive sales through a mix of marketing communication (Amin and Priansah, 2019). There needs to be an effort to campaign for self-help college activities in the community to get to know more about the advantages that have compared to other private universities (Stankevich, 2017). If this telemarketing program continues to be encouraged consistently then this will provide additional information that is required by prospective students (Y1lmaz \& Bhatti, 2017).

This telemarketing activity is not separated from the data base of prospective students. To get that data, colleges generally go down or come straight to school by handing out questionnaire questionnaires. Then in addition to the data of visits to the school the data base of prospective students is also obtained through social media to prospective students who ask on the social media status page Of Politeknik Unggul LP3M. Basically a good telemarketing program will be able to improve the decision to choose a lecture (Liana \& Suryawardani, 2018). So it is hoped that telemarketing program can help increase the number of students (Begam, 2020).

Private universities that have competent human resources will also assist in increasing the number (Shihab, 2019). Notoatmodjo (2003) in Sulasmi (2020) stated that human resource development is an effort to develop the quality or ability of human resources through the process of planning education, training and management of personnel or employees to achieve an optimal result. Face-to-face interactions with one or more prospective buyers with the aim of making presentations, answering questions, and procuring orders (Keller, 2012). Fornt office staff who are able to communicate and respond to all the information needed by prospective students are urgently needed by management. Therefore, training is required for the front office to be directly involved in the field of admissions of new students. Good personal selling ability will help especially prospective students in getting the various sources of information needed. So this will further increase confidence in the choice in determining which campus to choose (Fadli, 2020).

The image of the college has an importance in making the confidence level of a prospective student to choose a college (Norazah, 2018). The brand's ability to meet customers' psychological or social needs. Thus, individual factor related to customer behavior can be described as a strength remarking the customers as individuals which might influence the customer value (Kusumadewi (2019). Brand image can be formed directly (through consumer experience and its contact with products, brands, target market, or usage situation) and indirectly (through advertising and gethot tular communication) (Tjiptono, 2012). Every college will certainly continue to improve in building the image of the campus to the wider community. The main goal is to increase the value of confidence in prospective students (Fanani, 2018). In addition, the positive image of the college will also add to the feeling of pride to be part of the college (Zhang, 2015).

This research is very important to be done to provide a foundation for the management of LP3M Superior Polytechnic in determining the direction and policy measures to increase the number of new students. Furthermore, the results of this study can also provide hope for efforts to improve through medium and future telemarketing programs. Then the improvement of sales force or personal selling and the image of the campus should also be in line with the improvement of the existing telemarketing program. This aims that what has been promoted out will be the same as those on campus. So that will reduce the conflicts that occur in the future. 


\section{Review of Literature}

\subsection{Decision to Choose}

Every prospective student is also like a consumer who will maximize his income to get high satisfaction scores. The knowledge and experience that has been directed in analyzing the various alternative options of the college is in the brain. This is done so that the selected college will be able to answer its needs and desires (Danang Sunyoto, 2013). The efforts of universities in understanding the need for information or satisfaction values are expected to continue. This goal is certainly in line with what prospective students need in ensuring their choice (Tatik Suryani, 2013).

Almost every day a consumer will get various advertisements or information about further education programs (Sumarwan, 2011). Any incoming ads or information will be selected on the consumer's memory. At any given moment consumers will try to remember the ads or information that is important in the alternative selection process they are facing. Once an alternative is evaluated, consumers are ready to make a purchase decision. Sometimes buying intentions do not result in actual purchases (Ali Hasan, 2013).

\subsection{Telemarketing}

Many service companies today choose telemarketing programs in increasing sales volume. Telemarketing was chosen by the company because it is considered efficient and able to increase the company's revenue (Begam, 2020). So at this time of year where the tendency of each company will be to conduct a live search and ask what kind of product or service it wants. In practice this telemarketing can be distinguished over telemarketing into or known as inbound telemarketing. In this program a consumer who asks the company directly about the products or services offered. Consumers get contact person, website or even catalog that is intentionally promoted by the company. Furthermore telemarketing comes out or is known as outbound telemarketing. The difference with the previous program is that the company is more eager to find no consumers and try to offer its products (Keller, 2012). The results of research conducted by (Amerta, 2017) (Hufron, 2018) (Fata, 2019) suggest that telemarketing programs are very helpful for companies in improving a consumer's purchasing decisions.

\subsection{Personal Selling}

Personal selling can be interpreted as the company's efforts directly to consumers through sales people with the aim of offering products and services as well as providing harmonious relationships (Keller, 2012). The ability of a sales person to effect prospective new students is very important to have (Chandra, 2016). As a sales person who is required to learn about the products he sells (Nilamsari, 2018). Jaman as a sales person is also expected to be an ambassador or representative of the company in building partnership relationships with alumni students (Lupiyoadi, 2013). So personal selling is one of the strong origins why a consumer wants to choose a college to buy (Nasib, 2019). Previous research has stated that personal often with good communication skills will encourage prospective students to decide to choose the college (Sangen, 2019) (Yudhiartika \& Haryanto, 2012) (Natalia, 2018).

\subsection{University Image}

The reputation of the college often gets attention for prospective students as well as parents (Nasib dan Ratih Amelia, 2018). Consumers certainly have many altrenative choices from the many product advertisements it receives (Norazah, 2018). A brand with a good label among the wider community will have a positive impact on the encouragement in consumers 
to make purchases (Jorie, 2015) (Atmaja, 2016). So efforts to maintain the brand to be good wajid are carried out by the company to keep its excesses compared to its competitors (Khuzaini, 2016). Furthermore, the success of the company in maintaining its brand will be a clear identity against the value of differentiating with other brands (Ali Hasan, 2013). Surely this is a benefit for the company so that the brand of products produced is easily recognized by the broad community (Danang Sunyoto, 2013). Previous research has further emphasized that products with a good brand image will be difficult to match with newcomer brands (Foster, 2016) (Roring, 2018)(Roring, 2018) (Nurul Huda, 2020).

\subsection{Theoretical Frame of Mind}

In providing research direction to clarify the problem, the theoretical frame of mind in this study can be described the following:

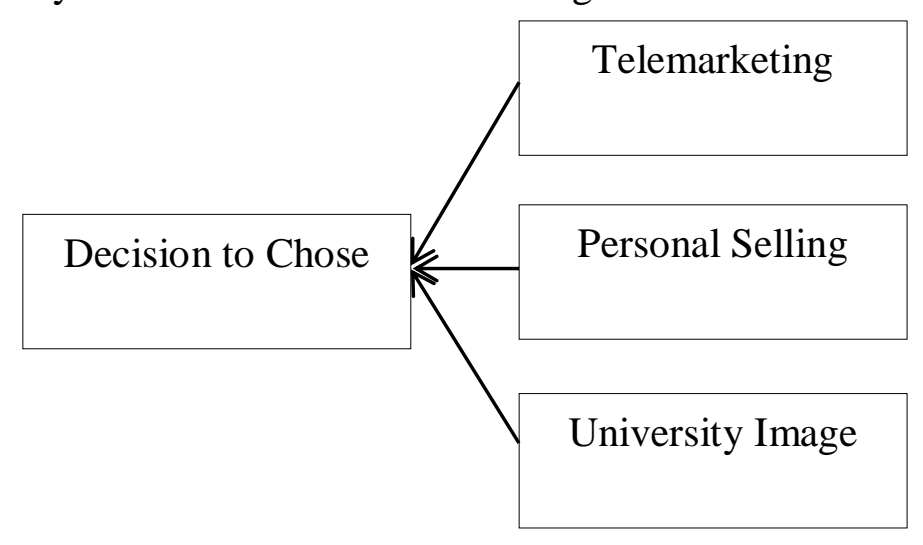

Figure 1. Theoretical Frame of Mind

\section{Research Methods}

Researchers chose a quantitative research model. Where in this model it is expected to be able to see the extent of the contribution of its influence telemarketing, personal selling and the image of the college in improving or even lowering the decision of a prospective student to choose a college. Furthermore, the population and sample are colon students where in this case there are students who have just graduated from high school in Medan. Sample withdrawal technique using snowball sampling. So the sample was 237 students who were interested in attending college. To obtain research data, the data collection method uses geogle forms that are shared directly to 237 through the respondent's WhatsApp contacts.

\section{Result and Discussion}

\subsection{Contents of Results and Discussions}

The data processing results can be shown in the table below:

Table 1. Data Processing Results

\begin{tabular}{|l|l|l|l|l|}
\hline Influence & $\mathbf{t}_{\text {count }}$ & \multicolumn{1}{|c|}{$\mathbf{F}_{\text {count }}$} & Sig & \multicolumn{1}{c|}{ Results } \\
\hline $\mathrm{X} 1-\mathrm{Y}$ & 1,610 & - & 0,109 & Insignificant positives \\
\hline $\mathrm{X} 2-\mathrm{Y}$ & 4,980 & - & 0,846 & Insignificant positives \\
\hline $\mathrm{X} 3-\mathrm{Y}$ & 17,285 & - & 0,000 & Positive and significant \\
\hline $\mathrm{X} 1 \mathrm{X} 2 \mathrm{X} 3-\mathrm{Y}$ & - & 187,907 & 0,000 & Positive and significant \\
\hline
\end{tabular}




\subsection{The Influence of Telemarketing on College Decisions}

Telemarketing in this study shows a positive but insignificant contribution in improving a prospective student's college decision. Telemarketing conducted during the Covid 19 pandemic conducted by the marketing team is not very effective to influence prospective students in applying. The results of this study are in line with previous research conducted by (Liana \& Suryawardani, 2018) (Nuralam, 2018) (Begam, 2020) which stated telemarting is able to increase purchasing decisions although not significantly. The implications of the findings that researchers get that in the condition of covid 19 pandemic, prospective students are still very much facing the results of the announcement of The Joint Selection of State College Admission (SBMPTN). So when the marketing team follow up to the prospective student the answer is all on average waiting for the results of SBMPTN. In addition there is no certainty that when they do not graduate at a public college they will have to attend a private college.

\subsection{The Effect of Personal Selling on College Decisions}

The results showed that personal selling has a positive influence in improving a prospective student's college decisions. The results of this study are in line with the results of previous research conducted by(Ridwanuddin, 2017) (Widaningsih, 2019) (Candraningrum, 2020) which stated that personal selling has a refresher in improving the sentness of lectures. Based on the findings that researchers get that in covid conditions like this the average prospective student is not too affected by personal selling owned by private universities. Prospective students do not see the figure of the lecturer. They prefer to delay not continuing college in the future.

\subsection{The Influence of Higher Education Image on College Decisions}

Based on the results of the study obtained that the image of the college has a positive and significant influence on college decisions. These results support previous research conducted by (Fadli, 2020) (Fanani, 2018) (Apriliani, 2019) which states that the image of universities is able to improve college decisions. There are implications for the findings that researchers found that campuses with negative brands such as indicated sales of diplomas, college processes that are considered easy to graduate and promised to get full scholarships do not get a good response especially for prospective fresh students. This is evident with many private colleges offering cheap tuition with good quality. So for stakeholders to maintain a good brand must be done to avoid the perception of prospective students in choosing a college.

\section{Conclusion}

The implications of the findings in this study suggest that all variable telemarketing, personal selling and college imagery have a positive influence in improving the college decisions of prospective freshman. However, the variable image of the college has the most contribution in encouraging prospective freshman to determine which campus to choose. 


\section{References}

Ali Hasan. (2013). Marketing dan Kasus-Kasus Pilihan. Yogyakarta: CAPS (Center for Academic Publisher Service).

Amerta, I. M. J. I. M. P. A. A. M. M. I. M. S. (2017). The marketing mix affect on the consumer buying decision (case study of sausage products at PT. Aroma Denpasar). International Journal of Social Sciences and Humanities, 1(2), 65-74. https://doi.org/10.29332/ijssh.v1n2.44.

Amin, M.A.S and Priansah, P. (2019). Marketing Communication Strategy To Improve Tourism Potential. Budapest International Research and Critics Institute-Journal (BIRCI-Journal), P. 160-166.

Amron, A. (2018). The Influence of Brand Image, Brand Trust, Product Quality, and Price on the Consumer's Buying Decision of MPV Cars. European Scientific Journal, 14(13), 228-239. https://doi.org/10.19044/esj.2018.v14n13p228

Apriliani, R. A. E. (2019). Pengaruh Brand Trust, Brand Equity dan Brand Image Terhadap Loyalitas Pelanggan (Studi Pada Pelanggan Teh Botol Sosro di Wonosobo). Jurnal Penelitian Dan Pengabdian Kepada Masyarakat UNSIQ, 6(2), 112-121. https://doi.org/10.32699/ppkm.v6i2.687

Atmaja, N. P. C. D. (2016). Pengaruh kewajaran harga, citra perusahaan terhadap kepuasan dan loyalitas pengguna jasa penerbangan domestik garuda Indonesia di denpasar. In Prosiding Seminar Nasional Hasil Penelitian (pp. 197-209).

Azhari, T. (2017). Pengaruh Experiental Marketing Dan Brand Trust Terhadap Loyalitas Nasabah Dengan Kepuasan Nasabah Sebagai Variabel Intervening Di Bnk BRI Syariah. Universitas Islam Negeri Syarif Hidayatullah Jakarta.

Begam, S. (2020). Impact Of Telemarketing On Retail Enterprises; A Csae Of Madurai City In Tamil Nadu. International Journal of Multidisciplinary Researches, 6(4), 28-33.

Budiarto, S. (2011). Pemasaran Industri: Business to Business Marketing. Yogyakarta: Andi Offset.

Candraningrum, N. A. D. A. (2020). Pengaruh Personal Selling terhadap Minat Beli Produk PRUlink Generasi Baru Nasabah Prudential Life Assurance Indonesia. Prologia, 3(2), 313-319. https://doi.org/10.24912/pr.v3i2.6348

Chandra, E. (2016). Hubungan Direct Marketing Dan Personal Selling Terhadap Keputusan Pembelian Pie Elis. Jurnal Manajemen Dan Start-Up Bisnis, 1(4), 414-423.

Danang Sunyoto. (2013). Dasar-Dasar Manajemen Pemasaran (Cetakan 2). Yogyakarta: CAPS.

Fadli, N. M. Z. F. A. (2020). Analysis Of Impact Factors On College Decisions On Private College Lecture In Medan City. International Journal of Business and Management Invention (IJBMI), 9(3), 18-24.

Fanani, F. K. Z. A. D. (2018). Pengaruh Citra Merek Terhadap Keputusan Pembelian (Survei Kepada Para Siswa Sman 15 Surabaya Kelas XII Yang Menggunakan Laptop Ber Merek Asus). Jurnal Administrasi Bisnis (JAB), 56(1), 75-81.

Fata, A. I. H. M. A. (2019). The Impact Of Marketing Approach Changes To School's Selection Decision. BISMA (Bisnis Dan Manajemen), 12(1), 54-65. https://doi.org/10.26740/bisma.v12n1.p54-65

Foster, B. (2016). Impact of Brand Image on Purchasing Decision on Mineral Water Product "Amidis" (Case Study on Bintang Trading Company). American Research Journal of Humanities and Social Sciences, 2(1), 1-11. https://doi.org/10.21694/2378-7031.16023 
Hidayat, D. I. D. L. R. (2017). Pengaruh Citra Merek dan Harga terhadap Keputusan Pembelian pada Sekolah Sekolah Tinggi Ilmu Manajemen Sukma Medan. Jurman Ilman, 5(1), 15-24.

Hufron, A. K. M. M. M. (2018). Pengaruh Direct Marketing, Sales Promotion Dan Persepsi Harga Terhadap Minat Beli Konsumen. E-Jurnal Riset Manajemen, 7(7), 34-45.

Jorie, A. R. R. J. (2015). The Effect Of The Price, Promotion, Location, Brand Image And Quality Products Towards The Purchase Decision Of Consumers At Bengkel Gaoel Store Manado Town Square. Jurnal EMBA, 3(2), 592-604.

Keller, P. K. K. L. (2012). Manajemen Pemasaran Edisi 12. Jakarta: Erlangga.

Khuzaini, N. P. N. (2016). Pengaruh Personal Selling, Brand Image, Word of Mouth terhadap Keputusan Pembelian Mobil. Jurnal Ilmu Dan Riset Manajemen, 5(1), 1-18.

Kusumadewi, R. (2019). The Role of Marketing and Individual Environment Association in Elevating the Customer Value. Budapest International Research and Critics InstituteJournal (BIRCI-Journal), P. 451-460.

Liana, S., \& Suryawardani, B. (2018). Pengaruh Telemarketing Terhadap Keputusan Pembelian Pada Astra Credit Companies Bandung Tahun 2018. In e-Procededing of Applied Science (Vol. 4, pp. 1248-1253).

Lupiyoadi, R. (2013). Manajemen Pemasaran Jasa Teori Dan Praktik. Jakarta: Salemba Empat.

Nasib. (2019). Optimalisasi Personal Selling, Lokasi Dan Harga Dalam Meningkatkan Keputusan Mengikuti Program Kepemilikan Rumah KPR Tipe 36. Jurnal Mantik Penusa, 3(1), 14-20.

Nasib dan Ratih Amelia. (2018). Pengaruh Kualitas Pelayanan, Harga Dan Citra Kampus Terhadap Loyalitas Mahasiswa Mengikuti Program MGM (Member Get Member) Melalui Kepuasan Mahasiswa Sebagai Variabel Intervening. Abdi Ilmu, 1(1), 121-133.

Natalia, I. N. P. S. E. (2018). Pengaruh Merek Dan Personal Selling Terhadap Keputusan Pembelian Produk DVD Player Elecor Pada PT. Cakrawala Elecorindo Medan. Jurnal Niagawan, 7(2), 80-89.

Nilamsari, L. P. (2018). Analisis Pengaruh Margin Dan Personal Selling Terhadap Minat Nasabah. Jurnal Al-Amwal, 10(1), 81-90. https://doi.org/10.24235/amwal.v10i1.1694

Norazah, J. S. (2018). Effects of Brand Association, Brand Loyalty, Brand Awareness, and Brand Image. International Journal of Retail \& Distribution Managemen, 34(1), 1-5.

Nuralam, J. A. M. A. F. D. I. P. (2018). Pengaruh Telemarketing Terhadap Keputusan Pembelian (Survei Online pada Pelanggan Produk Multiguna Astra Credit Companies Priority di PT Astra Sedaya Finance). Jurnal Administrasi Bisnis, 58(2), 21-28.

Nurul Huda. (2020). Pengaruh Brand Image Terhadap Keputusan Pembelian Motor Scuter Matic Yamaha Di Makasar. Jurnal Lembaga Keuangan, Ekonomi Dan Bisnis Islam, 2(1), 37-43.

Ridwanuddin, A. A. P. O. (2017). Pengaruh Personal Selling Terhadap Keputusan Berkunjung Di Jendela Alam. Tourism and Hospitality Essentials Journal, 6(2), 1077. https://doi.org/10.17509/thej.v6i2.5518

Roring, M. W. P. L. M. F. (2018). Pengaruh Brand Image Terhadap Keputusan Pembelian Produk Herbalife (Studi Kasus Pada Lima Nutrition Club Manado). Jurnal EMBA, 6(3), 1608-1617.

Sangen, A. M. (2019). Pengaruh Content Marketing, Sales Promotion, Personal Selling, Dan Advertising Terhadap Minat Beli Konsumen Pada Hotel Biuti Di Banjarmasin. Jurnal Sains Manajemen Dan Kewirausahaan, 3(1), 42-47.

Setyowati, W. P. M. Y. R. (2019). Pengambilan Keputusan Menentukan Jurusan Kuliah Ditinjau Dari Student Self Efficacy Dan Persepsi Terhadap Harapan Orang Tua. Jurnal 
Psikologi Pendidikan \& $\quad$ Konseling, $\quad 5(1), \quad 42-48$. https://doi.org/10.26858/jppk.v5i1.7460

Shihab, D. G. M. S. (2019). The Effect of Product Quality, Price and Promotion on the Purchase Decision of Telkomsel Service Products. International Journal of Innovative Science and Research Technology, 4(9), 419-425.

Stankevich, A. (2017). Explaining the Consumer Decision-Making Process: Critical Literature Review. Journal of International Business Research and Marketing, 2(6), 7 14. https://doi.org/10.18775/jibrm.1849-8558.2015.26.3001

Sulasmi, E. (2020). The Development Strategy of Human Resources Management In Children's Social Welfare Institution (LKSA) (Case Study in LKSA AL-Mubaraak Orphanage Bengkulu). Budapest International Research and Critics Institute-Journal (BIRCI-Journal), P. 562-569.

Sumarwan, U. (2011). Perilaku Konsumen: Teori dan Penerapannya dalam Pemasaran. Bogor: Ghalia Indonesia.

Susanto, B. B. D. (2019). Pengaruh Komunikasi Pemasaran Dan Motivasi KOnsumen Terhadap Keputusan Siswa Untuk Kuliah Di Aademi Komunitas Dharma Bhakti Bangka. Jurnal Ekonomi Dan Manajemen STIE Pertiba Pangkalpinang, 5(1), 12-21.

Suwendra, I. D. A. J. A. I. K. K. I. W. (2014). Faktor-Faktor Yang Mempengaruhi Keputusan Mahasiswa Dalam Memilih Jurusan Di Fakultas Ekonomi Dan Bisnis (Feb) Universitas Pendidikan Ganesha (Undiksha) Sebagai Tempat Kuliah. Journal Bisma Universitas Pendidikan Ganesha Jurusan Manajemen, 2(1), 1-8.

Tatik Suryani. (2013). Perilaku Konsumen di Era Internet. Yogyakarta: Graha Ilmu.

Tjiptono, F. (2012). Strategi Pemasaran Edisi 3. Yogyakarta: Andi.

Widaningsih, D. F. S. (2019). Pengaruh Personal Selling Terhadap Minat Beli Tabungan Berjangka (Taska) (Studi Kasus Bank Woori Saudara Bandung) Effect Of Personal Selling On Buying Interest Tabungan Berjangka ( Taska ) (Study Case : Bank Woori Saudara Bandung). In e-Proceeding of Applied Science (Vol. 5, pp. 82-90).

Y1lmaz, D., \& Bhatti, F. (2017). The Impacts of Direct Marketing Strategies on Consumers' Purchasing Decision in Cosmetic Sector in Turkey. Organisational Studies and Innovation Review, 3(2), 45-53.

Yudhiartika, D., \& Haryanto, J. (2012). Pengaruh Personal Selling, Display, Promosi Penjualan Terhadap Kesadaran Merek Dan Intensi Membeli Pada Produk Kecantikan Pond'S. Dian Yudhiiartika; Jony Oktavian Haryanto, 17(2), 142-156.

Zhang, Y. (2015). The Impact of Brand Image on Consumer Behavior: A Literature Review. Open Journal of Business and Management, 03(01), 58-62. https://doi.org/10.4236/ojbm.2015.31006 